\title{
ВЫДАЮЩИЙСЯ РОССИЙСКИЙ ЭКОНОМИСТ МИКАИЛ ИВАНОВИЧ ТУГАН-БАРАНОВСКИЙ
}

Аннотация. Рассматривается научное наследие получившего мировое признание выдающегося русского экономиста М. И. Туган-Барановского, открывшего Западу российскую экономическую мысль. Будучи историком, социологом, общественным деятелем, он исследовал проблемы развития русского капитализма, теоретические проблемы экономической науки, социалистические учения.

Ключевые слова. Промышленные кризисы, русский капитализм, экономические категории ценность и стоимость, кооперация, проблема бумажных денег, этический социализм.

M. A. Rogachevskaya Siberian Institute of Management - Branch of RANEPA, Novosibirsk, Russian Federation

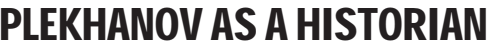 OF SOCIO-ECONOMIC THOUGHT}

Abstract. The paper considers the scientific heritage of the outstanding worldwide renowned Russian economist M. I. Tugan-Baranovsky that introduced Russian economic ideas to the West. Being a historian, sociologist, public figure, he researched the problems of the development of Russian capitalism, theoretical problems of economic science, socialist doctrines.

Keywords. Industrial crises, Russian capitalism, economic categories of value and cost, cooperation, problem of paper money, ethic socialism. 
Европейские учёные-экономисты привыкли смотреть на российскую экономическую науку свысока. Они полагали, что в лучшем случае россияне способны интерпретировать достижения европейской мысли. Русским языком они не владели, а потому трудов российских учёных в подлинниках не читали. Они как бы отгородились каменной стеной непонимания от достижений русской науки. Брешь в этой стене удалось пробить М. И. Туган-Барановскому в 1901 г.

Профессор Михаил Иванович Туган-Барановский, стал одним из первых русских экономистов, получивших мировое признание. Своими трудами он привлёк внимание западных экономистов и к произведениям российских учёных. Переведённые на иностранные языки его труды по общим проблемам экономической науки получили известность на Западе. Ряд высказанных им теоретических положений становился предметом широких научных дискуссий. Работы, относящиеся к социалистическим учениям, не оставляли равнодушными представителей различных идейно-теоретических течений. С ним ожесточённо спорили и отечественные и зарубежные марксисты.

Туган-Барановский, уважая мнение оппонентов, внимательно относился к их оценкам. Он стремился к познанию истины и поэтому на научном поприще не допускал колебаний, связанных с компромиссами с совестью или конъюнктурой.

Высокую оценку его творчеству давали многие отечественные и зарубежные экономисты и социологи: Карл Каутский, Эдуард Бернштейн, Пётр Струве, Сергей Булгаков, Вернер Зомбарт, Эйген Бём-Баверк, Джон М. Кейнс, Уэсли Митчелл и др.

Русский учёный оставил значительное теоретическое наследие, судьба которого в отечестве и за рубежом сложилась неоднозначно. В Советском Союзе в первые послереволюционные годы его труды ещё переиздавались, но в 30-е годы вышла только «Русская 
фабрика в прошлом и настоящем» (двумя изданиями), и до 1989 г. его работы не издавались. Туган-Барановский объявили «буржуазным идеологом», «пособником контрреволюции», его научные концепции, отнесли к «легальному марксизму» и из учебных программ соответствующих вузов и факультетов удалили изучение его произведений. Он не был совершенно забыт только потому, что стал объектом нелицеприятной критики, его мысли и суждения искажались, и даже имя часто уничижительно сокращалось до «Туган» или «Т-Б-ский».

На Западе его работы продолжали выходить и до и после Второй мировой войны. Они издавались во Франции, в Германии, Польше, Англии, США, Чехословакии, Японии, Швейцарии, Италии. Его имя было хорошо известно в научных кругах, ещё и потому, что многие крупные экономисты: К. Каутский, И. Фишер, Дж. М. Кейнс, Т. Веблен, Й. Шумпетер, Б. Селигмен и другие учёные писали о нём книги, цитировали его труды. Всего за рубежом специально Туган-Барановскому и его произведениям было посвящено более ста работ.

Мы можем гордиться тем, что в изданном в США в 1987 г. биографическом справочнике ведущих экономистов за период 1700-1986 годы, М. И. Туган-Барановский назван выдающимся русским учёным с мировым именем.

В советский период скромное освещение научной деятельности этого учёного было дано лишь в многотомном издании «История Русской экономической мысли», носившее явно тенденциозный характер [2, с. 358-389, 401-404, 409-412]. Короткую информацию о нём поместила Экономическая энциклопедия «Политическая экономия» [16, с. 205].

Картина изменилась в настоящее время. Его произведения возвратились на полки библиотек из спецхранов, где они были почти недоступны широ2017. T. 18, № 4. C. 613-649 
ким кругам читателей. Переизданы его произведения: «Социальные основы кооперации» (1989), «К лучшему будущему» (1996), «Периодические промышленные кризисы. История английских кризисов. Общая теория кризисов» (1997), «Очерки из новейшей истории политической экономии и социализма» и «Бумажные деньги и металл», вошедшие в сборник «Экономические очерки» (1998), «Основы политической экономии» (1998). Теперь стало возможным познакомиться со взглядами и мыслями замечательного экономиста, непосредственно обращаясь к его произведениям, а не к пересказу с чужих слов. Его вклад в экономическую науку стал изучаться и в высшей школе. В курсе лекций, опубликованных в 2000 г. Г. Н. Сорвиной, имеется посвящённая ему лекция: «Политическая экономия М. И. Туган-Барановского - первого российского экономиста с мировым именем» [6, с. 88-122]. Выпущенный Сибирским государственным университетом учебник М. А. Рогачевской «История экономических учений» содержит специальный раздел: «Российская школа экономической мысли», в которой значительное место занимает глава «Экономические воззрения М. И. Туган-Барановского» [5, с. 229-249]. Имеются указания на его произведения и в других учебных изданиях.

Своё истинное призвание М. И. Туган-Барановский определил не сразу. Учился он на физико-математическом факультете Харьковского университета. Но осознав, что подлинной сферой его интересов являются общественные науки, он сдал экстерном экзамены и за юридический факультет. Таким образом, в 1889 г. он получил образование на двух факультетах физико-математическом и юридическом. Но главной и, пожалуй, единственной сферой его научной деятельности стала политическая экономия.

Увлечение политической экономией пришло к нему в университете. Свободно владея пятью языками 
он читал в подлиннике западноевропейскую литературу. Большое значение в выборе пути имело его знакомство с «Капиталом» Маркса, трудами Менгера «Основы политической экономии», Визера «О происхождении и основных законах экономической ценности», Бём-Баверка «Основы теории ценности хозяйственных благ». Даже темой дипломной работы за юридический факультет он избрал «Причину ценности», что говорит о его заявке на серьезные научные намерения.

С этого момента молодой юрист погружается в мир социальных идей, экономических проблем, важнейших общественных движений.

Становление Туган-Барановского как экономиста-теоретика пришлось на 90-е годы XIX столетия. В этот период Россия, благодаря деятельности С. Ю. Витте, тесными нитями вплеталась в мировое хозяйство, обнаруживая мощные и яркие признаки капиталистического развития. Происходящие изменения в социально-экономической действительности вызвали подъём общественной мысли. Научные, публицистические труды экономистов: А. И. Чупров, Н. Х. Бунге, Н. И. Зибер, И. И. Янжул, Б. Н. Чичерин и др. охватывали широчайший круг проблем, актуальных для того времени.

Первой научной работой, написанной М. И. Туган-Барановским в 1890 г. для «Юридического вестника» была статья «Учение о предельной полезности». За ней последовали книги биографического содержания о П. Ж. Прудоне и Д. С. Милле в которых он проявил несомненные литературные способности.

Михаил Иванович углубляется в изучение современной ему экономической литературы. С большим интересом он продолжает изучать второй том «Капитала» К. Маркса и произведения так называемой австрийской субъективной школы, к которой примыкали труды английских, швейцарских, американских и шведских учёных, превратив её в интернациональную. 
Его развитие как учёного происходило естественным образом: узнавание нового; отказ от прежних концепций, как ошибочных; восприятие оригинальных идей. Он обладал богатой природной умственной одарённостью. Ему был присущ в высшей степени интуитивный талант, и как таковой, он вспыхивал и блистал, поражая даже тех, кто его близко знал, - вспоминал Н. Д. Кондратьев, его ученик, сам впоследствии ставший знаменитым учёным.

Первую крупную теоретическую работу «Промышленные кризисы в современной Англии, их причины и ближайшее влияние на народную жизнь» (1894) Туган-Барановский посвятил одному из «самых любопытных и своеобразных явлений» капитализма - проблеме рынка и кризисов [7]. Она доставила ему в научных кругах России огромную популярность. В том же году он защитил её при Московском университете как магистерскую диссертацию. Она принесла ему признание и за рубежом, после издания её в Германии в 1901 г.

Бурные общественные споры и политические дискуссии, побудили Туган-Барановского обратиться к промышленного развития России, определив труд как «Русская фабрика в прошлом и настоящем» (1898) [9]. Эту работу он также защитит в качестве докторской диссертации при Московском университете. Оперируя огромным арсеналом фактов, чётко выверенной логикой интерпретации истории экономического развития России, диссертант аргументированно доказывал, что Россия вошла в круг капиталистических государств. Это означало, что обществоведческий вопрос, «по какому пути следует идти России?», уже снят реальным ходом экономического прогресса. Россия, хотя и с некоторыми своими особенностями, уже идёт по капиталистическому пути.

Основательное знание трудов экономистов-теоретиков позволило Туган-Барановскому творчески 2017 , vol. 18 , no. 4 , pp. $613-649$ 
осмыслить ход развития экономической мысли. Он сотрудничает со многими журналами: пишет статьи, очерки, рецензии, а также предисловия к издаваемым трудам. Его научное наследие поражает своим многообразием. Учёный откликается на важнейшие проблемы, которые ставит перед экономической наукой российская и мировая действительность. Это исследования в области рынков и кризисов, развития капитализма и теории распределения, проблемы кооперативного движения, история экономических воззрений, история и теория социализма.

За сравнительно короткий период им созданы весьма важные в теоретическом и социальном отношении произведения: «Очерки из новейшей истории политической экономии и социализма» (1903), «Теоретические основы марксизма» (1905), «Современный социализм в своём историческом развитии» (1906), учебник «Основы политической экономии» (1909), «К лучшему будущему» (1912), «Социальная теория распределения» (1913), «Социальные основы кооперации» (1916), «Бумажные деньги и металл» (1917), последнее произведение, опубликованное при жизни учёного было «Социализм как положительное учение» (1918).

М. И. Туган-Барановский скончался в 1919 г. в возрасте 54 лет.

\section{Учение о промышленном цикле}

Важную роль для научного авторитета М. И. Туган-Барановского и для признаниязначимости русской экономической мысли сыграло им решение проблемы промышленных кризисов. Совсем ещё молодым учёным, делавшим первые шаги в науке, Туган-Барановский смело взялся за решение одной из самых сложных проблем экономического развития, чётко определив её в заглавии своей книги: «Промышленные кризисы в современной Англии, их причины и ближайшее влияние на народную жизнь». К этой проблеме он будет 2017. T. 18, № 4. С. 613-649 
обращаться еще не раз. Готовя переиздание книги в России, дополняя и перерабатывая содержание, он уточнял и формулировку названия ${ }^{1}$. Установив причину кризиса, о которой он писал в недавно опубликованной книге, Михаил Иванович продолжает думать о ней, хотя уже работает над «Русской фабрикой». Анализ статистических материалов позволяет ему сделать вывод, что Россия приближается к промышленному кризису. Читатели книги, вышедшей в начале 1898 г., не поверили сделанному указанию, но в 1899 г. кризис произошёл

Книга о промышленных кризисах привлекла к себе внимание германских экономистов, пожелавших иметь её немецкое издание. Имея в виду сложность материала, Туган-Барановский сам переводит свой труд на немецкий язык. Готовя перевод, он поинтересовался данными о состоянии промышленности в Германии, и высказал мнение, что Германия приближается к промышленному кризису. Книга «Промышленные кризисы», изданная в 1901 г., имела огромный успех. Учёный сам объяснил его причину: «В немецком издании я высказал мнение, что Германия приближается к промышленному кризису; кризис последовал в 1901 г., что обратило на себя большое внимание немецкой печати» [7, Предисловие к третьему изданию].

Позже он предсказал и американский кризис 1907 года [8, с. 538].

Аксиомой стало в экономической науке представление о неожиданности возникновения кризисных явлений. О возможности прогнозирования кризисов мечтали и теоретики, и практики. Успехов ни в Евро-

1 Второе издание, вышедшее в 1900 г., названо «Промышленные кризисы. Очерк из социальной жизни Англии», а третье «Периодические промышленные кризисы. История английских кризисов. Общая теория кризисов» (1914). Это уже было «совершенно переработанное издание». В России и СССР книга издавалась 5 раз, иностранные издания были в США, Японии, Швейцарии. 
пе, ни в Америке не было. И вдруг решение пришло из России!

Каким образом удалось Туган-Барановскому прогнозировать возможность кризисов? Несомненно, это было не случайностью, а результатом научного знания. Самой загадочной и поражающей воображение особенностью капиталистического развития, пишет Туган-Барановский, является свойственная ему цикличность. Рост капиталистического производства идёт не по прямой, а волнообразно. Последовательные подъёмы и падения этих волн совершаются с такой правильностью, что напоминают явления скорее природного, а не социального характера [8, с. 519].

Учёный исследует этот процесс на примере Англии, страны, прошедшей наиболее продолжительный путь капиталистического развития, в которой капитализм раныше других стран познакомился с кризисами. Обратив внимание на то, что Англия в XIX в. каждое десятилетие переживала фазы подъёма и упадка промышленности, он приходит к выводу о необходимости изучения истории кризисов, их причины и особенно условий перехода к подъёму.

Он убеждён, что ни одно теоретическое исследование невозможно без знания условий возникновения и развития явления. Анализ изученных трудов экономистов, в той или иной степени затрагивающих проблемы реализации и кризисов, позволил ему сосредоточить внимание на проблеме движения совокупного общественного продукта и капитала, рассмотренной К. Марксом в теории воспроизводства и промышленного цикла.

Размышления о месте и значении реализации в воспроизводственном процессе привели Туган-Барановского к необходимости исследования рынка. «Рынок, - писал он, - это узел, где сплетаются нити современной хозяйственной жизни. Рынок управляет производством, а не производство рынком. ...Рынок 2017. T. 18, № 4. С. 613-649 
является, таким образом, центральной силой, управляющей всем капиталистическим хозяйством, а недостаток его, эластичной повязкой, задерживающей его развитие». Он подчёркивает, что «трудность сбыта постоянно существующая и возникающая проблема рынка, разрешение которой долгое время было не под силу экономической науке» [8, с. 495, 510].

При анализе проблемы рынков Туган-Барановский использует метод схематического построения общественного производства как единого целого, и приходит к ряду оригинальных выводов. Так, он устанавливает, что размеры рынка отнюдь не определяются размерами народного потребления, так как произведённый общественный продукт состоит из предметов потребления и средств производства. Поэтому проблема реализации может быть решена при соблюдении определённой пропорциональности между отраслями общественного производства. А если этого нет, то народное хозяйство будет развиваться скачками, переходя от периода подъёма к периоду депрессии.

Но частная собственность на средства производства, рассуждает далее Туган-Барановский, и свободная конкуренция не допускают возможности организации производства в масштабах общества². Предприниматели работают на неизвестный им рынок; капитал, расширяясь, сталкивается с постоянными трудностями, вызванными неспособностью капитализма обеспечить соответствующую пропорциональность общественного воспроизводства. Именно это обстоятельство и является непосредственной причиной промышленных кризисов. Капитал, постоянно давящий на производство, форсирует его и порождает тенденцию к перепроизводству. Будучи следствием внутрен-

2 Книга, посвящённая промышленным кризисам, была написана в 1894 г., когда промышленный капитализм только вступал в эпоху господства монополий.

2017, vol. 18, no. 4, pp. 613-649 
них причин, органически присущих капитализму, оно вызывает трудности сбыта и кризис.

Правильно чередующиеся периоды промышленного подъёма и упадка своей совокупностью образуют то, что можно назвать капиталистическим циклом, заключает учёный. Цикл закономерно проходит несколько неизменно сменяющих друг друга фазисов подъёма, кризиса и депрессии. Возникает вопрос: чем обусловлена периодичность? Почему подъём обязательно заканчивается кризисом? На эти вопросы он и ищет ответы.

Чтобы начался подъём, необходимо достаточное количество свободных капиталов. Исследуя процесс накопления производительного и денежного капитала, учёный обратил внимание на существенное различие ихдинамики. Производительному капиталу свойственна цикличность, т. к. его движение проходит периоды спадов и подъёмов. Стать источником накопления свободных капиталов в период депрессии производительный капитал не может. А среди источников денежного капитала имеются не зависящие от колебаний промышленной конъюнктуры: доходы получателей земельной ренты, держателей государственных ценных бумаг, военнослужащих, чиновников, пенсионеров. В период застоя они могут откладывать в сбережения часть получаемых ими доходов. Поступающие в банки денежные средства этих групп населения, накапливаясь, становятся тем необходимым свободным капиталом, который, достигнув пороговой величины, способен привести в движение промышленность, прежде всего, в отраслях, производящих средства производства.

По мере усиления подъёма, происходит расширение производства и постепенное исчерпание свободного капитала, приводя к росту ссудного процента. Предложение на рынке постепенно начинает опережать спрос, рыночная конъюнктура ухудшается, товарные цены падают ниже издержек производства. 
Кризисные явления перерастают в кризис. Так представляет себе Туган-Барановский механизм циклического движения капиталистического хозяйства.

Высказав мысль о возможности прогнозирования конъюнктуры, учёный поразил западных экономистов. Он выявил симптомы приближающихся изменений. Так, симптомами промышленного подъёма являются оживление деловой активности, повышение товарных цен, рост общественного спроса. Они, прежде всего, сказываются на производстве металла. (Эта точка зрения позже стала общепризнанной. Подъём сталелитейной промышленности и рост цен на сталь оказались весьма точным индикатором начала выхода из кризиса.) Гораздо большее значение в промышленных кругах приобрёл симптом приближающегося кризиса: прекращается повышательное движение биржевых курсов (иногда приводящее к биржевому спаду), начинается неуклонный рост дисконтного (учётного) процента, обнаруживается понижательная тенденция товарных цен.

Именно, на основе наблюдения этих симптомов Туган-Барановский предсказал ряд кризисов в России, Германии, США, прогнозы которых сбылись. Продолжение исследования эволюции капиталистического воспроизводства привело его к обнаружению изменения характера колебаний промышленного производства. К концу XIX - началу XX в. исчезли острые кризисы, произошёл переход от скачкообразного к волнообразному характеру движения экономики, которому Туган-Барановский дал название «волны». Но какую бы форму промышленный цикл не принимал, он был предопределён самой природой капиталистического хозяйства.

Таким образом, Туган-Барановский выявил причины периодичности кризисов; превратил теорию кризисов в теорию конъюнктуры; исследовал конъюнктуру на основе статистического метода, анализируя 
фактическую историю английского классического капитализма; установил ряд признаков, определявших каждую фазу цикла, позволяющих прогнозировать движение конъюнктуры и возможность воздействовать на неё.

Трактовка цикла, данная Туган-Барановским, отличалась от традиционной, принятой в марксистской экономической литературе. Учёный не считает кризис важнейшей фазой цикла. По его мнению, кризисы не являются симптомами приближающейся смерти буржуазного строя, а лишь - острым и болезненным средством самокорректирования экономики капитализма. Важнейшая роль в цикле принадлежит фазе подъёма. До тех пор, пока капитализм сохраняет способность к расширению производства, до тех пор, пока он в состоянии обеспечивать себе подъём, он будет бороться за своё существование. Но капитализм неминуемо уступит своё место социализму, более совершенному строю, хотя причина, по его мнению, будет находиться не в экономической, а в социальной, этической сфере.

«Периодические кризисы» Туган-Барановского исследование, далеко вышедшее за пределы анализа капиталистического цикла. По существу, им была создана оригинальная теория хозяйственной конъюнктуры, на основе которой правительства получили возможность делать научные прогнозы социально-экономического развития, определять направление экономической политики государства. «Самой важной работой из, несомненно, впечатляющего наследия М. И. Туган-Барановского является история торговых кризисов в Англии. Она занимает важное место в нашей науке», заметил известный историк экономической науки Й. Шумпетер [15, с. 1481].

М. И. Туган-Барановский не только по справедливости получил мировое признание, но он оказался и родоначальником целой школы, изучавшей проблемы экономической конъюнктуры. К ней примкнули из 2017. T. 18, № 4. C. 613-649 
отечественных экономистов В. Я. Железнов, В. К. Дмитриев, Н. Д. Кондратьев, а из зарубежных - А. Шпитгоф, Ж. Лескюр, Г. Шмоллер, А. Ноув.

\section{Возникновение русского капитализма}

Туган-Барановский был подлинным русским учёным, и его весьма волновали проблемы, стоящие перед страной. Конец XIX в. был для России эпохой споров о путях её развития, но это было и время, когда началось бурное развитие российской промышленности. Завершение труда, посвящённого исследованию капиталистического развития Англии, побудило учёного исследовать возникновение русского капитализма. Результатом его, явилась книга «Русская фабрика в прошлом и настоящем» ${ }^{3}$ [9].

Первое издание книги вызвало интерес не только в России, но и за рубежом. В 1909 г. в Берлине вышел ее перевод на немецком языке под названием «Geschichte der russische Fabrik» («История русской фабрики»).

Учёный показывает, что в отличие от европейских стран российская крупная промышленность, а, следовательно, и капитализм вырастают в специфических экономических условиях. К концу XIX века уже сформировался торговый капитал. Существовала крупная промышленность, представленная казёнными предприятиями преимущественно военного назначения. Особенностью русской промышленности дореформенного периода являлось господство несвободного, принудительного труда. Рынок свободной рабочей силы стал формироваться лишь после отмены крепостного права. Становится свободным весь применяемый труд, преобразуется социально-экономическая основа производства. Технический прогресс и расширение рынков создаёт прочную базу для развития современной фабрики с её механическими двигателями

${ }^{3}$ Книга издавалась в России и СССР - семь раз. За рубежом она была издана в Германии в 1909 и в США в 1970 г. 
и массовым производством. Фабрика начинает быстро оттеснять кустаря и занимать господствующее положение в производстве и на рынке.

В своей книге Туган-Барановский показывает возникновение купеческой фабрики («посессионной мануфактуры»), специфический продукт экономических условий петровской России, вместе с дворянской (вотчинной) мануфактурой, образовавшей фундамент частного предпринимательства, основанного на принудительном труде. Развиваясь в течение XVIII века, купеческая фабрика и дворянская мануфактура преобразовались в дворянскую фабрику, которая, постепенно отмирая в николаевскую эпоху, замещалась новейшей капиталистической фабрикой.

Одновременно с этим процессом шёл другой, имея своим источником «курную избу». В XIX в. появились крестьянские мануфактуры, создаваемые разбогатевшими крестьянами. По мнению Туган-Барановского это «характеризует новую эпоху в развитии нашей крупной промышленности», ибо они явились «органическим продуктом народной жизни», и не могут быть «искусственным явлением, подобно фабрикам позапрошлого века». Он прослеживает как изменялся в различные эпохи состав «фабрикантского» класса и слагался класс фабричных рабочих. Особое внимание уделяется исследованию взаимных отношений крупной и мелкой промышленности в крепостной России, когда русская фабрика ещё не знала машин и в конце XIX века, когда они стали применяться повсеместно. Вывод, к которому приходит экономист, очевиден: «Условия русской промышленности созрели уже до промышленного капитализма. Крепостная фабрика, по ходу промышленной эволюции отживала своё время, её место занимала новая, капиталистическая фабрика, основанная на свободном договоре предпринимателя-капиталиста с наёмным рабочим» $[9$, с. 557].

2017. T. 18, № 4. С. 613-649 
В книге «Русская фабрика в прошлом и настоящем» и позднее в учебнике «Основы политической экономии» (1909), Туган-Барановский высказывает свою точку зрения на особенности русской экономической истории, наложившие глубокий отпечаток на многие политические, идейные, нравственные процессы, присущие нашей стране.

Характерной чертой русской промышленности была высокая концентрация производства. «Капитализму, - подчеркнул важную особенность экономического развития России Туган-Барановский, - не приходилось разрушать высокую экономическую культуру иного типа; вот почему наш капитализм, не встречая никакого сопротивления, легко складывается в формы, ещё не достигнутые странами, стоящими по своему хозяйственному развитию далеко впереди нас» [9, с. 574.].

Исследование Туган-Барановского о совершенствовании капитализма показывает, что на определённой ступени исторического развития, по мере того как создаются более свободные правовые условия, растёт экономическая свобода и конкуренция, увеличивается внутренний и внешний рынок, и становятся более тесными взаимные торговые связи, в стране развивается капитализм. А он, в свою очередь, ускоряет технический и социальный прогресс общества.

В орбиту капиталистических отношений втягиваются и менее развитые страны, приводя к перемещению капитала из развитых стран в страны молодой культуры, и тем самым форсируется экстенсивно-пространственный рост капитализма. Туган-Барановский стремился рассматривать экономику любой страны во взаимодействии с другими странами, поскольку в теоретических исследованиях, полагал он, нельзя отрываться от реальной действительности, чтобы не получить неверный результат. 


\section{Проблемы экономических категорий ॥ценность॥ и ॥стоИмость"}

Экономические отношения во всём своём многообразии и полноте были исследованы Туган-Барановским в учебнике «Основы политической экономии» (1909), который по существу представлял научный труд, содержащий глубокий критический анализ истории политической экономии, западных и отечественных теорий, появившихся на рубеже XIX и XX веков, сравнительный анализ микро- и макроэкономических проблем.

Третье издание учебника было удостоено Императорской Академией наук большой премии. «До самого последнего времени у нас на русском языке не имелось ни одного курса политической экономии, преследующего чисто научные задачи. Новая работа М. И. Туган-Барановского, восполняя этот пробел, ...равно как и удивительное искусство автора излагать просто и ясно самые запутанные и трудные вопросы делает её доступной самой широкой публике», - писал о ней известный русский экономист-математик В. К. Дмитриев. В своей рецензии в журнале «Русская мысль», написанной вскоре после выхода учебника, Дмитриев назвал его «Новым русским трактатом по теории политической экономии» [1, с. 494].

Среди рассматриваемых теорий самой сложной и дискуссионной проблемой оказалась, по мнению Туган-Барановского, теория ценности. Это объясняется тем, что он писал книгу в эпоху обострённой борьбы между сторонниками теории ценности австрийской школы (теории предельной полезности) и сторонниками марксистской теории трудовой ценности. В России полемика «приобрела» политическую окраску. Учёный не мог быть в стороне, но занял в этом споре научную позицию, обосновав необходимость научного решения проблемы.

2017. T. 18, № 4. C. 613-649 
В его концепции народного хозяйства категории «ценность» и «стоимость» являются основополагающими. Он считал, что обе категории вытекают из самой природы хозяйственного процесса, которая, с одной стороны, всегда «преследует» цель - приспособление внешней природы к нашим потребностям, а с другой стороны - достижение этой цели, путём некоторых затрат, составляющих «средство для достижения цели».

Прежде всего, Туган-Барановский устанавливает логическую взаимосвязь: «затраты - результат», между которыми как между двумя полюсами заключена хозяйственная деятельность. Любой производитель стремится получить наибольшую сумму хозяйственной пользы при наименьших затратах. Поэтому «ценность», по его мнению, всегда связана с «целью», а «стоимость» со «средством». Ценность для него - одна, а стоимость - другая сторона хозяйства. Хозяйство, с одной стороны, преследует известную цель, интерес, выгоду, и этой его стороне соответствует категория ценности. С другой стороны, хозяйство прибегает к известным средствам, затратам, усилиям, и этой стороне его деятельности соответствует категория стоимости. Трудовая стоимость, в конечном счете, означает «затрату труда человека, его способностей, т. е. личности как естественно активного делателя хозяйства» $[8$, с. 39, 55].

Таким образом, обе теории ценности исследуют различные стороны одного и того же хозяйственного процесса. Теория предельной полезности выясняет субъективные, а трудовая теория - объективные факторы хозяйственной ценности.

Учёный считает, что существовавшие теории ценности (трудовая и предельной полезности) каждая по-своему верны, но односторонни, так как объясняют ценность произведённых благ только на основе объективных или субъективных факторов ценности. Теории 
эти, несомненно, противоположны, но не противоречивы. Они не исключают, а дополняют друг друга, определяя ценность с объективной и субъективной сторон. Только синтез теорий трудовой ценности и предельной полезности может окончательно решить проблему ценности хозяйственных благ. «Считаю, важнейшей задачей нашего времени в области экономической теории, - писал он, - органический синтез обоих направлений» [8, с. 49, 50, 54].

Развитие общественного производства, соответствующее уровню удовлетворения определённых человеческих потребностей, доказывает Туган-Барановский, может быть обеспечено в том случае, если «полезность последних единиц свободно воспроизводимых продуктов каждого рода - их предельная производительность - должна быть обратно пропорциональна относительному количеству этих продуктов, производимому в единицу рабочего времени, иначе говоря, должна быть прямо пропорциональна трудовой стоимости тех же продуктов. ...Таким образом, обе теории ценности ...находятся в действительности, в полной гармонии друг с другом» [8, с. 52, 53].

Зависимость между величиной ценности блага и его трудовой стоимости получила в литературе название «теоремы Туган-Барановского». Во второй половине XX в. её стали широко применять при решении проблемы экономического оптимума.

Высказанная позиция Туган-Барановского вызвала ожесточённую, продолжавшуюся многие годы критику. Его упрекали в измене марксизму и научному анализу за «восхваление» теории предельной полезности; его стали считать буржуазным апологетом, ревизующим учение Маркса. Зарубежные социалисты так же считали первоначально позицию Туган-Барановского недобросовестной фальсификацией науки с буржуазными целями. Однако позже им пришлось согласиться с тем, что теория предельной полезности или маржи2017. T. 18, № 4. C. 613-649 
нализм, это теория действительно научная, изучающая экономические проблемы, функционирующие в рыночной среде.

\section{Учение о кооперации, её сущности и историческом значении}

Хотя за вековой период существования кооперативного движения о проблемах кооперации было написано множество книг и статей практически во всех европейских странах, но написанная Туган-Барановским в 1916 г. книга «Социальные основы кооперации» ${ }^{4}$, сразу привлекла к себе внимание. В этом фундаментальном труде автор обобщил опыт мирового кооперативного движения, глубоко изучив заложенные в нём идеи, определял пути развития кооперации вплоть до её значения в социалистическом движении. Книга была результатом многолетних изысканий и размышлений, завершившаяся созданием «общей теории кооперативного движения во всех его многосложных проявлениях». Н. Д. Кондратьев дал ей такую оценку: «Работы М. И. Туган-Барановского по вопросам кооперации, несомненно, нужно признать выдающимися, одними из лучших, и не только у нас в России» [3, с. 88].

Потребность в обобщающей теоретической работе остро ощущалась в России. Михаил Иванович объяснял это тем, «что русское кооперативное движение развивается в иных условиях, чем на Западе». Там, это движение народных масс, стоящих на почве ближайших практических нужд, а «у нас кооперация, и охватив миллионы населения, всё же находится под сильным влиянием интеллигенции, желающей служить интересам трудящихся классов». Поэтому именно в России на первый план выступила потребность «в разработке кооперативной теории, выясняющей смысл и задачи движения» $[10$, с. 42, 43].

${ }^{4}$ Книга издавалась в России 5 раз, в Польше 2 раза и в Израиле 1 раз. 
Туган-Барановский разработал теорию кооперации, новую область экономической науки, теснейшим образом связанную с практикой хозяйственного развития России. Книга стала необходимой и востребованной не только в России. Её переводы были изданы во многих странах. И она не забывается до сих пор. Е. Домар в «Американском экономическом обозрении» за 1966 год отметил: «Очень интересная книга по кооперации была опубликована М. И. Туган-Барановским». Впервые в мировой экономической литературе был дан многосторонний анализ кооперативного предприятия - его хозяйственных особенностей, социальной природы, места в рыночной капиталистической экономике.

Для Туган-Барановского было очевидным, что кооперация - это «организация трудящихся общественных классов в их борьбе с капиталистами». Развивая эту мысль, учёный уточняет: «Так как кооперативы одна из форм самозащиты трудящихся классов от неблагоприятных для них условий хозяйствования, они существуют только в среде трудящихся классов. А поэтому можно различать кооперативное движение среди пролетариата, крестьянства и промежуточного класса мелкой буржуазии» [10, с. 106].

Важнейшей формой кооперации, по мнению Туган-Барановского, является пролетарская кооперация. Он доказывает, что наиболее устойчивыми являются потребительские пролетарские кооперативы, тогда как производительные пролетарские артели быстро сходят со сцены.

На основе обобщения исторического опыта развития сельскохозяйственной кооперации в странах Западной Европы и России учёный приходит к выводу, что важнейшие черты кооперации - самостоятельность и самодеятельность. Особо он подчёркивает значение личной заинтересованности членов кооператива в достижении высоких экономических 2017. T. 18, № 4. C. 613-649 
результатов. При этом он подчёркивает, что духовной основой кооперации может быть только солидарность интересов.

Кооперация призвана воспитать нового человека, гармонично сочетающего в себе способность отстаивать личные интересы с готовностью отказаться (самому!) от них во имя общего интереса.

В отделе, посвящённом мелкобуржуазной кооперации, автор обращает внимание на то, что «все особенности экономической организации объясняются особенностями и экономическими интересами того общественного класса, в среде которого она создавалась и получила развитие» [10, с. 349]. Мелкобуржуазная кооперация имеет тенденцию к превращению в капиталистические товарищества и союзы.

Рассматривая кооперацию в России, Туган-Барановский отмечает, что пролетарская кооперация в России почти не развита потому, что рабочие не в состоянии выделить из своей заработной платы средства, необходимые для паевого взноса в потребительский кооператив, чтобы противостоять хозяйским лавкам. Что же касается сельскохозяйственной кооперации, то таких стремительных темпов роста не знала ни одна страна Западной Европы. По числу кооперативов и членов в них Россия занимала первое место в мире.

Кооперативное движение в русской деревне отличалось большим разнообразием. Но самой блестящей страницей нашего кооперативного движения, считал ученый, являлась маслодельная кооперация. Это был хозяйственный вид кооперативов, сумевший достичь огромного экономического значения на основе самодеятельности самого населения.

Определяя социальную основу кооперации, Туган-Барановский отмечал, что она «представляет собой прямо противоположную (капиталистической) систему хозяйства. В ней царит не капитал, не вещь, а человек, личность. И для успеха кооперации требует- 
ся господство в душе человека не жажды богатства, а чувство общественной солидарности. Вот почему кооперативное хозяйство настоятельным образом требует воспитания соответствующего человека» [10, с. 434].

Теоретическая разработка проблем кооперации сыграла большую роль в окончательном оформлении представлений Туган-Барановского о социальном идеале. Он пишет: «Свободная кооперация найдёт в социалистическом обществе широкое применение. ... Когда капитализм сойдёт с исторической арены... Общество должно до конца превратиться в добровольный союз свободных людей, - стать насквозь свободным кооперативом. Таков социальный идеал, который полностью никогда не будет достигнут, но в приближении к которому и заключается весь исторический процесс человечества» $[10$, с. 448, 449].

Туган-Барановский несколько идеализировал кооперативное движение, создавая своеобразную кооперативную утопию. Не со всеми его высказываниями можно согласиться, да этого и не требуется. Прошло сто лет после написания им работы. Нынешний этап требует иного подхода к анализу кооперации. Перед крестьянством Российской Федерации вновь возникла необходимость восстановления кооперативного движения. Мысли учёного опять стали актуальными. Но кардинально изменилась деревня, изменилась социальная среда, появились иные жизненные ориентиры. Теперь деревне требуется «новый человек», целью деятельности которого будет достижение общественного благосостояния, обеспечение достойных условий труда и жизни сельских тружеников. Не подлежит сомнению, что в современных условиях для подъёма кооперативного движения, для обретения им силы противостоять воинствующему бюрократизму, необходима поддержка общества, опирающаяся на теорию кооперации, разработанную М. И. Туган-Барановским. 


\section{Теория денег. Проблема бумажных денег}

Теорию денег Туган-Барановский изложил в учебнике «Основы политической экономии» (глава «Деньги») и брошюре «Бумажные деньги и металл». Понимание им проблемы денег и денежного обращения опирается на солидный фундамент научной отечественной и зарубежной литературы. Он неоднократно отмечал, что теория денег относится к числу сложнейших в политической экономии и продолжает развиваться, обусловленная вступлением денег в новый фазис своего развития.

Он утверждает: «Законодательных актов, впервые создавших деньги, не было, деньги возникали всегда незаметно и постепенно. Они неизбежно появлялись у всех народов на известной ступени развития. Обмен сам собой порождает деньги» [8, с. 111]. Раскрывая эволюцию денег, учёный подчеркнул, что в борьбе за существование в роли денег победителями вышли золото и серебро.

По его мнению, деньги выполняют три основных функции: быть мерилом ценности товаров; орудием обмена товаров; законным платёжным средством. При этом подчёркивает, что первые две функции возникли стихийно, ещё до образования какого-либо государства и поэтому не могут быть результатом государственного решения. «Из названных основных функций денег вытекают производные: средства сохранения ценности (деньги как сокровище); средства перемещения ценности; орудия кредита». Именно способность предмета выполнять все функции денег и делает предмет деньгами. Туган-Барановский добавляет: «и если золото и серебро стали деньгами во всём мире, то лишь потому, что именно эти металлы... всего лучше могут выполнять указанные функции» [8, с. 244, 245].

Важнейшая функция денег - быть мерилом ценности товаров означает, что деньги по природе своей должны иметь товарное происхождение. Золото и се- 
ребро, прежде чем стать деньгами, были товаром. Став деньгами, золото и серебро оказались обладателями особой потребительной ценностью и устойчивой меновой ценностью. Они - принадлежность сферы обращения. Их высокая и устойчивая ценность обусловливается достаточной редкостью месторождений золота и серебра, большими издержками производства и постоянной высокой потребностью в них. Исследуя проблему, что происходит с золотом (серебром), когда оно из товарного мира переходит в мир денег, учёный рассуждает: «деньги по своей внутренней природе не являются товаром. Товар может стать деньгами, но, функционируя в качестве денег, он не функционирует в качестве товара и наоборот». Наиболее отчётливо это «глубокое различие экономической природы товара и денег обнаруживается в бумажных деньгах, не имеющих никакой внутренней ценности и, тем не менее, выполняющих все функции денег (в том числе и мерила ценности)». [8, с. 246-247].

Хотя деньги возникли как результат стихийного обмена, но, когда в этой роли стали выступать металлы, их функционирование было санкционировано государственной властью, признающей данный предмет законным платёжным средством. В разных странах деньги изготавливались из разных металлов, имели разную форму и вес, но, в конечном счёте, наиболее приемлемой оказалась форма диска, используемая до сих пор.

Туган-Барановский показывает трансформацию денег за более чем двухтысячелетнюю историю монетного обращения, в котором участвовали полноценные и неполноценные монеты. Вследствие роста потребности в монетах и недостатка в металлах, стала происходить их порча. Внимание учёного привлекли бумажные деньги, обусловив исследование объективной неизбежности их появления и особенности функционирования. Он устанавливает генетическую связь 2017. T. 18, № 4. C. 613-649 
бумажных денег с металлическими. Деньги, весьма дорогое орудие обмена, «которое как таковое, никаким другим общественным потребностям не служит. Для общества было бы очень выгодно, если бы было возможно создать такие деньги, которые ничего бы ему не стоили, а представляли собой лишь простые условные знаки. В этом и заключается идея бумажных денег, символических изображений денег, которые должны заменить металлические деньги и исполнять их функции» [8, с. 262-263].

Собственная ценность бумажных денег основывается на том, что государство признаёт их законным платёжным средством. Необходимо только придать им такую же устойчивую ценность, которой обладают золотые и серебряные деньги.

Такой эксперимент был поставлен в конце XIX в., когда правительствами многих стран проводились реформы перевода валют на золото. Туган-Барановский, учёный-теоретик, проанализировал с научных позиций ход денежных реформ, проведённых в России и Австрии. Обе страны стремились перевести денежное обращение на золотую основу. Россия к 1897 г. сумела накопить достаточное количество золота, необходимого для свободного размена кредитных билетов. Правительство опасалось ажиотажного спроса на золото, когда будет объявлен на него размен кредитных билетов. Для министра финансов С. Ю. Витте было полной неожиданностью, что население, предпочитая банковские билеты более удобными в торговых сделках и других платежах, не спешило обменивать кредитные билеты на звонкую монету. Золотые и серебряные монеты, не будучи востребованными, оставались в кассах Государственного Банка. Их пришлось «вталкивать»в обращение.

По мнению учёного, реформа была проведена успешно, но для научного анализа, для развития теории денег она материала не дала. 
Иное произошло в Австрии. Замысел реформы был такой же, как и в России. Вместо серебряного гульдена вводилась новая денежная единица - золотая крона. Но размен пришлось отложить, т. к. золотой запас Австро-Венгерского Банка к 1892 г. оказался для размена недостаточным. Хотя к 1899 г. необходимый золотой запас был накоплен, однако ни население, ни промышленники и торговцы не спешили отказываться от бумажных денег. Частные банки так же успешно работали с бумажной валютой. В 1899 г. Австрийское правительство сделало беспрецедентный шаг, - введя новый денежный закон, по которому размен бумажных крон на золото был отложен на неопределённое время. Австрия стала первой страной с бумажной валютой, обладающей такой же устойчивой ценностью, как и металлические деньги. «В этом и заключается то существенно новое, что дал нам опыт Австрии. Можно утверждать, что со времени новейшего австрийского законодательства бумажные деньги вступили в новый фазис своего развития» [11, c. 328].

Туган-Барановский замечает, что, несмотря на всю важность проблемы ценности денег, экономическая наука к началу $X X$ в. ещё не имеет общепризнанной теории ценности денег 11, с. 285]. Он считал, что центральным вопросом в теории денежного обращения, является вопрос о факторах, управляющих ценностью денег. Это привело его к необходимости проанализировать количественную теорию денег, исследовать влияние на экономику быстрого и значительного увеличения количества денег в обращении. По мнению учёного, колебание добычи благородных металлов не оказывает влияния на изменение количества и ценности денег, так как наличные запасы благородных металлов в обращении всего мира настолько громадны, что ежегодная добыча слабо отражается на величине этих запасов. Только в области бумажно-денежного об2017. T. 18, № 4. C. 613-649 
ращения влияние этого фактора может быть учтено в полной мере.

Исходя из сказанного, Туган-Барановский выдвигает иное направление анализа новых процессов, протекающих в экономике и денежном обращении. Он установил зависимость ценности денег от общего уровня товарных цен в экономике, а, следовательно, и от состояния общественного производства в целом. Колебания товарных цен охватывают, приблизительно, десятилетие и связаны с промышленным циклом. «В восходящем фазисе промышленного цикла товарные цены растут; затем следует кризис, и цены начинают падать, чем характеризуется нисходящий фазис промышленного цикла». То же относится и к колебанию ценности денег. Поскольку промышленный цикл - типичное явление современного хозяйства, то и соответствующие ему колебания денежных цен «не находятся ни в малейшей связи с колебанием количества денег», то есть общим состоянием экономической конъюнктуры или, в частности, конъюнктурой товарного рынка [11, с. 320, 321].

Свою теорию денег Туган-Барановский назвал конъюнктурной. Эта теория имела большое значение для обоснования денежной реформы после окончания Первой мировой войны. В результате огромной инфляции, вызванной увеличением военных расходов и сокращением производства благ потребительского назначения как в России, так и в других воюющих странах, произошла деформация денежного обращения. Необходимо было осуществить укрепление бумажного рубля и придать ему устойчивую ценность при отсутствии размена на золото.

Конъюнктурная теории денег позволила М. И. Туган-Барановскому сделать вывод о возможности регулирования ценности бумажных денег в рыночной экономике, осуществляемого государством с целью обеспечения рационального денежного обращения, 
зависящего от конъюнктуры ${ }^{5}$. Мысль о возможности регулирования экономики, опираясь на бумажно-денежное обращение, была высказана российским экономистом за два десятилетия до Дж. М. Кейнса и за полвека до монетаристов.

\section{Учение об этическом социализме}

Проблемы социализма исследовались М. И. Туган-Барановским в работах: «Теоретические основы марксизма» (1906), «Современный социализм в своём историческом развитии» (1906), «Очерки из новейшей истории политической экономии и социализма» (1907), «К лучшему будущему» (1912), «Социальные основы кооперации» (1916), «Социализм как положительное учение» (1918) и др.

Рассматривая капитализм как исторически преходящий строй, и изучая условия его возникновения и развития, Туган-Барановский отмечал его прогрессивный характер, проявляющийся в значительном росте производительных сил. Вместе с тем он вскрывает и противоречия, свойственные этому строю. Частная собственность обусловливает стихийный характер производства и конкуренцию, вызывает проблему реализации и неизбежность кризисов. В отличие от Маркса он рассматривал промышленные кризисы не как симптом приближающейся смерти, а как острое и болезненное средство самокорректирования хозяйственного состояния капитализма. Среди противоречий, порождённых частной собственностью, учёный особо выделял антагонистические. Туган-Барановский писал по этому поводу: «Теория эксплуатации труда доказывает, что при современном устройстве обще-

5 Первое издание книги «Бумажные деньги и металл», вышедшей в 1917 г. в Петрограде, было утрачено. В 1919 г. в Одессе вышло 2-е посмертное издание книги. В настоящее время она опубликована в составе сб. «Экономические очерки». М., 1998. В советское время не публиковалась. 
ства целые классы населения - и притом составляющие огромное большинство его - обречены постоянно служить средством для увеличения благосостояния других общественных классов, менее многочисленных. Такое положение вещей противоречит этической идее равноценной личности» [12, с. 27]. Учёный убеждён, что глубинное противоречие между основой капиталистического строя и этой этической нормой находит своё выражение, прежде всего, в антагонизме интересов господствующих и трудящихся классов.

Исследуя развитие капитализма, он устанавливает усиление процесса пролетаризации населения, а вместе с этим и осознание пролетариатом своей роли в обществе. Рост сознательности пролетариата как класса, повышение его организованности и сплочённости, понимание и формулирование своих классовых интересов, в конечном итоге, приведёт к замене капиталистического общества социалистическим. Статистический анализ отчётливо показал, что вследствие развития социальных движений происходит улучшение материального положения пролетариата, всё более успешно противостоящего натиску капитала. Именно организованная борьба английского рабочего класса позволила ему значительно улучшить своё социально-экономическое положение, а вместе с ним и культурный уровень. Пролетариат, выработав свой социальный идеал, приступил к его осуществлению. Развитие новых форм классовой борьбы, таких как парламентаризм, кооперативное движение и укрепление рабочих союзов, ведут к подрыву экономического господства капитала.

Учёный убеждён: «Человечество не получит нового общественного уклада, как дара слепой игры экономических сил: оно должно этот новый строй сознательно выработать и завоевать. Капитализм никогда не умрёт естественной смертью - ему может быть нанесен смертельный удар лишь мыслью и волей челове- 
ка» [13, с. 229]. Произойдёт это, вне всякого сомнения, на высоком уровне развития экономики и производительных сил.

Критика капиталистического строя в воззрениях Туган-Барановского совпадает со взглядами Маркса. Но, будучи убеждённым гуманистом, он был противником теории насилия как единственной формы классовой борьбы. Его привлекала мысль Маркса, что «самоцелью человечества, истинное царство свободы, в котором происходит развитие человеческих сил, может расцвести на царстве необходимости, как на своём базисе, вследствие сокращения рабочего дня» [4, с. 387]. Туган-Барановский замечает, что «социальное развитие идёт постоянно и непрерывно; царство свободы растёт медленно, но неуклонно в недрах царства необходимости уже много тысячелетий, и каждый шаг человечества вперёд, есть новая область свободы, отвоёванная человеком у слепой и безжалостной необходимости».

Вместе с тем он полагает, что несмотря на рост рабочего движения во всех его формах, «приобретение политической власти пролетариатом есть более отдалённая цель социалистического движения нашего времени; практическая же, повседневная политика социализма ставит ближайшие задачи, осуществимые в пределах существующего строя. Сила марксизма в том и заключается, что в одно целое связаны борьба за далёкий идеал с борьбой за ближайшие интересы рабочего класса». Крах капитализма неизбежен, но не в обозримом будущем.

Туган-Барановский был убеждён, что в основе теории социализма должна лежать этическая идея верховной ценности человеческой личности, почерпнутая им у Иммануила Канта. Проблемы экономики и этики рефреном проходят через всё его творчество. Именно по этическим, а не по экономическим причинам на смену капитализму, где пролетарий - средство 2017. T. 18, № 4. C. 613-649 
для достижения целей владельцев средств производства, должно придти социалистическое общество, в котором человек станет высшей, главной ценностью. «В отличие от существующих систем хозяйства социализм стремится перенести возможно бо́льшую часть хозяйственных забот с индивида на общество, что равносильно освобождению личности человека, позволяя обеспечить её всестороннее развитие». Для достижения этой цели необходимо, прежде всего, уничтожить частную собственность на средства производства, нарушающую основной этический принцип равноценности человеческой личности. «...Благодаря равной обязанности трудиться и равному праву всех участвовать в пользовании плодами этого труда, невозможна эксплуатация одних членов общества другими» [12, c. 21,10$]$.

Потребности людей по своей природе не могут быть равны. Если социалистическое общественное устройство предполагает социальное равенство всех своих членов, оно должно совершенствовать управление производством, чтобы обеспечить наиболее полное удовлетворение духовных, физических и материальных потребностей, на основе изобилия общественного богатства, а не уравнительного принципа распределения.

Учёный понимает, что достижение цели социалистического общества должно быть обеспечено соответствующей структурой общественного производства. Её разработка поставила Туган-Барановского в ранг интересных и оригинальных мыслителей, подразделившего будущий строй на «социализм» в узком смысле слова, и на «коммунизм».

Из всех существовавших к началу XX в. социалистических идей, наибольшей поддержкой у марксистов пользовалась идея государственного социализма. Туган-Барановский в известной мере был с этим солидарен. При государственном социализме в руках 
государства сосредоточивается управление всем общественным хозяйством. «Социалистическая организация хозяйства может развить все присущие ей громадные производительные силы». Но несмотря на способность придать общественному производству пропорциональность и планомерность, обеспечить приспособление производства к общественным потребностям, система государственного социализма сохраняет элементы принуждения, что противоречит идее полного и свободного развития личности. По мнению Туган-Барановского, она не соответствует социальному идеалу. «Централизм всегда несёт с собой бюрократизм, ... игнорирование индивидуальных отличий, ... и принуждения» [14, с. 82]. Создание общественного богатства идёт за счёт принижения личности, превращения человека... в простого винтика гигантской государственной машины, и его положение мало чем будет отличаться от положения при капитализме.

Создавая теорию социализма, Туган-Барановский обращает внимание на проблему распределения. При социализме в силу недостаточности развития общественного производства предполагается нормирование доходов отдельных членов общества через заработную плату. Свобода потребления в рамках дохода не ограничивается. При коммунизме, когда будет достигнута высокая степень общественного производства, такого нормирования не потребуется, станет возможным распределение по потребностям.

Верный гуманистической идее этического социализма, учёный особо выделяет духовные потребности, безграничность развития которых совпадает с интересами личности и общества.

Почти во всех своих работах Михаил Иванович обращался к России, рассматривая социальные особенности её развития. В последних работах, написанных в 1918 году, он развивал мысль, что теперь «во всех областях хозяйственной жизни для России открывается 2017. T. 18, № 4. C. 613-649 
широкий простор для нового социального творчества, долженствующего всё более приближать Россию к социалистическому строю». Но, двигаясь в сторону социализма и постепенно приближаясь к последнему, Россия, делает неутешительный прогноз учёный, всё же в ближайшем будущем не станет социалистической страной». Много размышляя о возможности построения социализма в России, он понимал, что «до социализма современная Россия, безусловно, не дозрела», не допуская мысли о попытке построения социализма в недостаточно развитой стране. Он убеждён: «Человечество идёт к социализму, и, несомненно, его достигнет. Но, во всяком случае, к нему всего ближе наиболее культурные народы с высоко развитым чувством долга и общественной солидарности, с высоким уровнем народного просвещения» [14, с. 126].

М. И. Туган-Барановский - выдающийся учёный, великолепный педагог, блестящий писатель, своеобразный и гуманнейший человек, яркий представитель духовной культуры. Он умел видеть дальше других исследователей и у себя на родине и за рубежом. Он был первым русским учёным, заставившим западную науку обратить внимание на экономическую мысль России. Развитие политической экономии стало делом всей его жизни. В его трудах закладывался фундамент оригинальной научной школы, способной обогатить отечественную и мировую экономическую науку.

\section{Өписок использованной литературы}

1. Дмитриев В. К. Экономические очерки / В. К. Дмитриев. - М. : ГУ ВШЭ, 2001. - 580 с.

2. История русской экономической мысли. В 2 т. / под ред. А. И. Пашкова, Н. А. Цаголова. - М. : Соцэкгиз, 1960. T. 2, ч. 2 : Эпоха домонополистического капитализма. - 676 с.

3. Кондратьев Н. Д. Михаил Иванович Туган-Барановский / Н. Д. Кондратьев. - Петроград : Колос, 1923. - 125 с.

4. Маркс К. Сочинения. В 39 т. / К. Маркс, Ф. Энгельс. М. : Политиздат, 1962. - Т. 25, ч. 2 : Капитал. Т. 3. - 551 с. 
5. Рогачевская М. А. История экономических учений : учебник / М. А. Рогачевская. - Новосибирск : Сибирский государственный университет телекоммуникаций и информатики, 2006. - 309 с.

6. Сорвина Г. Н. Экономическая мысль XX столетия: страницы истории : лекции / Г. Н. Сорвина. - М. : РОССПЭН, 2000. - 224 c.

7. Абалкин Л. И. Избранное. Периодические промышленные кризисы. История английских кризисов. Общая теория кризисов / Л. И. Абалкин, М. И. Туган-Барановский. - М. : РОССПЭН, 1997. - 574 с.

8. Туган-Барановский М. И. Основы политической экономии. - 5-е изд. / М. И. Туган-Барановский. - Петроград : Право, 1918. - 760 с.

9. Туган-Барановский М. И. Избранное. Русская фабрика в прошлом и настоящем. Историческое развитие русской фабрики в XIX веке / М. И. Туган-Барановский. - М. : Наука, 1997. - 735 c.

10. Туган-Барановский М. И. Социальные основы кооперации / М. И. Туган-Барановский. - М. : Экономика, 1989. 496 c.

11. Туган-Барановский М. И. Бумажные деньги и металл / М. И. Туган-Барановский / / Экономические очерки. - М. : РОССПЭН, 1998. - 527 с.

12. Туган-Барановский М. И. Общественно-экономические идеалы нашего времени / М. И. Туган-Барановский. СПб. : Вестник знания, 1913. - 140 с.

13. Туган-Барановский М. И. Теоретические основы марксизма / М. И. Туган-Барановский. - СПб. : Мир божий, 1906. - 234 c.

14. Туган-Барановский М. И. Социализм как положительное учение / М. И. Туган-Барановский. - Петроград : Право, 1918. - 179 c.

15. Шумпетер Й. А. История экономического анализа. В 3-х т. / Й. А. Шумпетер. - СПб. : Экономическая школа, 2004. - T. 3. -1665 c.

16. Политическая экономия : экон. энциклопедия. В 4 т. / под ред. А. М. Румянцева. - М. : Советская энциклопедия, 1980. - T. 4. - 672 c.

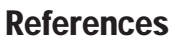

1. Dmitriev V. K. Ekonomicheskie ocherki [Economic essays]. Moscow, GU VShE Publ., 2001. 580 p. 
2. Pashkov A. I., Tsagolov N. A. (eds). Istoriya russkoi ekonomicheskoi mysli [History of Russian economic thought]. Moscow, Sotsekgiz Publ., 1960, vol. 2, iss. 2. 676 p.

3. Kondratiev N. D. Mikhail Ivanovich Tugan-Baranovskii [Mikhail Ivanovich Tugan-Baranovsky]. Petrograd, Kolos Publ., 1923. $125 \mathrm{p}$.

4. Marx K., Engels F. Sochineniya [Collected Works]. Moscow, Politizdat Publ., 1962, vol. 25, part 2. Capital, vol. 3. 551 p.

5. Rogachevskaya M. A. Istoriya ekonomicheskikh uchenii [History of economic doctrines]. Novosibirsk, Siberian State University of telecommunications and Informatics, 2006. 309 p.

6. Sorvina G. N. Ekonomicheskaya mysl' XX stoletiya: stranitsy istorii [The economic thought of the $20^{\text {th }}$ century: pages of history]. Moscow, ROSSPEN Publ., 2000. 224p.

7. Abalkin L. I., Tugan-Baranovskii M. I. Periodicheskie promyshlennye krizisy. Istoriya angliiskikh krizisov. Obshchaya teoriya krizisov [Periodic industrial crises. History of English crises. General theory of crises]. Moscow, ROSSPEN Publ., 1997. 574 p.

8. Tugan-Baranovskii M. I. Osnovy politicheskoi ekonomii [Basic concepts of political economy]. $5^{\text {th }}$ ed. Petrograd, Pravo Publ., 1918. $760 \mathrm{p}$.

9. Tugan-Baranovskii M. I. Izbrannoe. Russkaya fabrika v proshlom $i$ nastoyashchem. Istoricheskoe razvi-tie russkoi fabriki v XIX veke [Selected works. Russian factory in past and present. Historical development of the Russian factory in the XIX century]. Moscow, Nauka Publ., 1997. 735 p.

10. Tugan-Baranovskii M. I. Sotsial'nye osnovy kooperatsii [Social foundations of cooperation]. Moscow, Ekonomika Publ., 1989. 496 p.

11. Tugan-Baranovskii M. I. Paper money and metal. Ekonomicheskie ocherki [Economic essays]. Moscow, ROSSPEN, 1998. 527 p.

12. Tugan-Baranovskii M. I. Obshchestvenno-ekonomicheskie idealy nashego vremeni [Socio-economic ideals in our time]. Saint Petersburg, Vestnik znaniya Publ., 1913. 140 p.

13. Tugan-Baranovskii M. I. Teoreticheskie osnovy marksizma [Theoretical bases of Marxism]. Saint Petersburg, Mir bozhii Publ., 1906. 234 p.

14. Tugan-Baranovskii M. I. Sotsializm kak polozhitel'noe uchenie [Socialism as a positive doctrine]. Petrograd, Pravo Publ., 1918. $179 \mathrm{p}$.

15. Schumpeter J. A. History of Economic Analysis. London, Routledge, 1997. 1260 p. (Russ. ed. Shumpeter I. A. Istoriya ekonomicheskogo analiza. Saint Petersburg, Ekonomicheskaya shkola Publ., 2004. 1665 p.). 
16. Rumyantsev A. M. (ed.) Politicheskaya ekonomiya [Political economy]. Moscow, Sovetskaya entsiklopediya, 1980, vol. 4. 672 p.

\section{Информация об авторе}

Рогачевская Майя Антоновна - кандидат экономических наук, доцент, доцент кафедры финансов и кредита, Сибирский институт управления-филиал РАНХиГС, 630102, г. Новосибирск, ул. Нижегородская, 6, e-mail: mrogachevskaya@mail.ru.

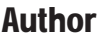

Maya A. Rogacherskaya - Candidate of Economic Sciences, Associate Professor, Senior lecturer of the Department of Finances and Credit, Siberian Institute of Management Branch of RANEPA, 630102, Novosibirsk, Nizhegorodskaya Str., 6, e-mail: mrogachevskaya@mail.ru.

\section{Для цитирования}

Рогачевская М. А. Выдающийся российский экономист Михаил Иванович Туган-Барановский / М. А. Рогачевская // Историко-экономические исследования. 2017. - T. 18, № 4. - C. 613-649. - DOI: 10.17150/23082588.2017.18(4).613-649.

\section{$47: 4 \cos ^{2}$}

Rogachevskaya M. A. Outstanding Russian Economist Mikhail Ivanovich Tugan-Baranovsky. Istoriko-ekonomicheskie issledovaniya $=$ Journal of Economic History $\mathcal{E}$ History of Economics, 2017, vol. 18, no. 4, pp. 613-649. DOI: $10.17150 / 2308-$ 2588.2017.18(4).613-649. (In Russian). 